\title{
Paying for Congress
}

\author{
Laura E. Hamilton ${ }^{t}$
}

Laura Hamilton is pursuing a master of public administration degree with a concentration in program evaluation and policy analysis. Ms. Hamilton is a Wolcott Fellow and a certified public accountant. She works as an evaluator for the U.S. General Accounting Office.

Citizens pay for the operation of Congress as well as the election and compensation of members of Congress. As a result, citizens expect a responsive national legislature. This expectation might be fully realized were it not for the one congressional expense that citizens do not fund: campaigns.

Wealthy individuals, political action committees (PACs), corporate and union supporters of political parties, and the candidates themselves pay for most campaign expenditures, and candidates are naturally inclined to spend money on and act in the interests of their financiers. Those interests often converge on one objective: winning.

Regrettably, the candidates' desire to win an election does not often produce what voters want-the motivation to go to the polls and the ability to make an informed choice. Citizens cannot expect much from campaigns financed by others.

The low expectations that voters have for congressional campaigns can be measured by voter turnout; roughly 60 percent of citizens stay home on a congressional election day. ${ }^{1}$ Research indicates that three factors-disbelief in government's responsiveness, disinterest in media coverage of campaigns, and lack of knowledge about candidates and issues-contribute to voters' decisions to ignore election day. ${ }^{2}$ To the extent that the current system of campaign finance reinforces voter apathy, the system is hopelessly flawed.

Many of the flaws in today's system can be corrected with the Voter Information Program (VIP). VIP asks citizens to pay only for the availability of enough information and dialogue to make an informed vote. Unlike traditional public financing schemes, this program would not allow candidates to freely spend taxpayers' funds. Under VIP, federal and state governments would appropriate funds for the sole purpose of producing voters' guides and organizing candidate debates. Voters' guides and debates would provide information about all candidates to all voters, enabling citizens to have and make a choice. VIP would supplement rather than replace the current campaign finance system to protect candidates' and contributors' rights to free speech while providing the information and competition that the voters desire. Armed with knowledge about issues and facing a slate of varied competitors, citizens would have more incentive to return to the polls.

\section{The Current System of Financing Congressional Campaigns}

The current system of financing congressional campaigns is based on an entrenched system of political and financial interests. The system allows the major campaign financiers-wealthy individuals, PACs, palty supporters, and the candidates themselves-to contribute more money in more ways to campaigns than most citizens. These financial supporters encourage the candidates to purchase services, such as advertising, campaign administration, and fund raising, that do not inform voters or consistently move citizens toward the polls.

The typical voter does not and could not finance the cost of today's campaigns for three reasons. ${ }^{3}$ First, only 10 to 15 percent of the electorate contribute to congressional campaigns. ${ }^{4}$ Second, many of these contributors are wealthy. Third, even if more citizens wanted to contribute, under the Federal Election Campaign Act (FECA), indivicluals are restricted to giving less money on a per capita basis than any other campaign donor (see Table 1). As Chart 1 indicates, half of candidates' financing comes from relatively less restricted contributors, which include PACs, political parties, and the candidates themselves. 


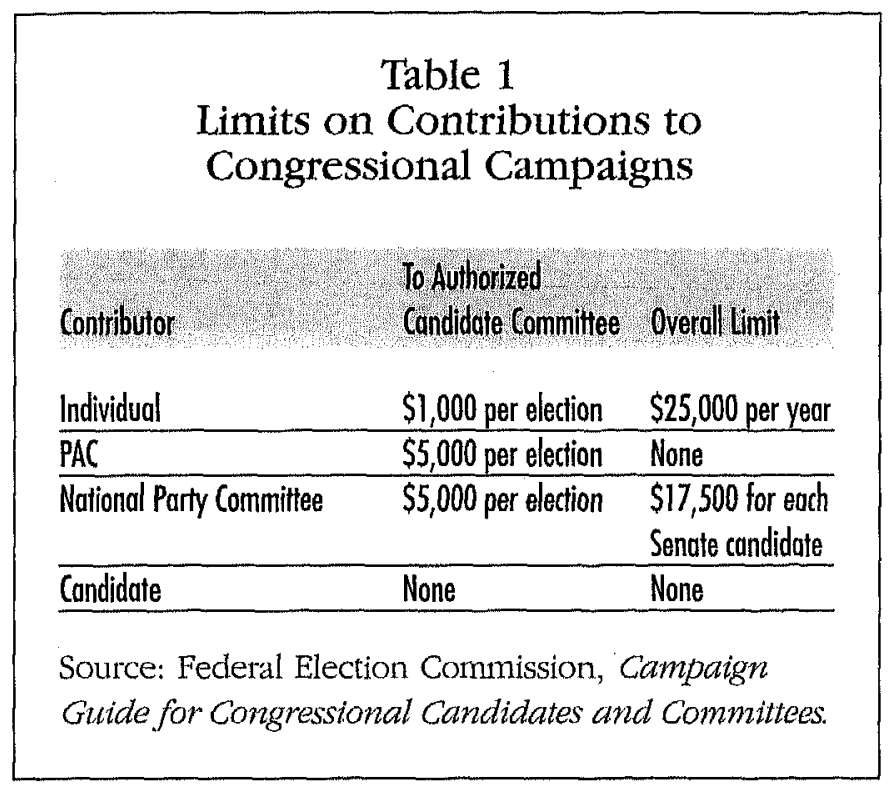

Although providing only 25 percent of congressional candidates' 1994 campaign receipts, PACs have a greater resource base and more means to finance campaigns than the typical voter. ${ }^{6}$ For example, if a PAC wants to contribute more than its $\$ 5,000$ per candidate limit, PAC members can be asked to write individual checks which the organization will "bundle" and present to the candidate, or a PAC might consider making an independent expenditure. The typical voter does not have these options.

Because PACs have more resources and more ways to contribute to campaigns, citizens perceive that candidates are more responsive to PACs. In addition to affecting citizens' perception of government's responsiveness, PACs also affect the competitiveness of today's campaigns. PACs have consistently provided most of their contributions to incumbents. 'The strong PAC preference for incumbents effectively removes one source of funds for challengers.

Although chailengers can look to political parties for financing, parties contribute little directly to campaigns. ${ }^{10}$ More often, parties finance candidates' campaigns with coordinated expenditures, which allows parties to buy a limited amount of research, polling, and advertising for candidates. ${ }^{11}$ However, coordinated expenditures and contributions to candidates are relatively small sources of funding, in part because of limits on how much parties can receive for and give to congressional campaigns. ${ }^{12}$

Political parties wield much of their influence in congressional campaigns by collecting unlimited contributions of soft money (funds raised or spent outside the provisions of federal election law). ${ }^{13}$ The parties can spend soft money in

\section{Chart 1: Sources of 1994 Congressional Campaign Contributions, All Candidates}

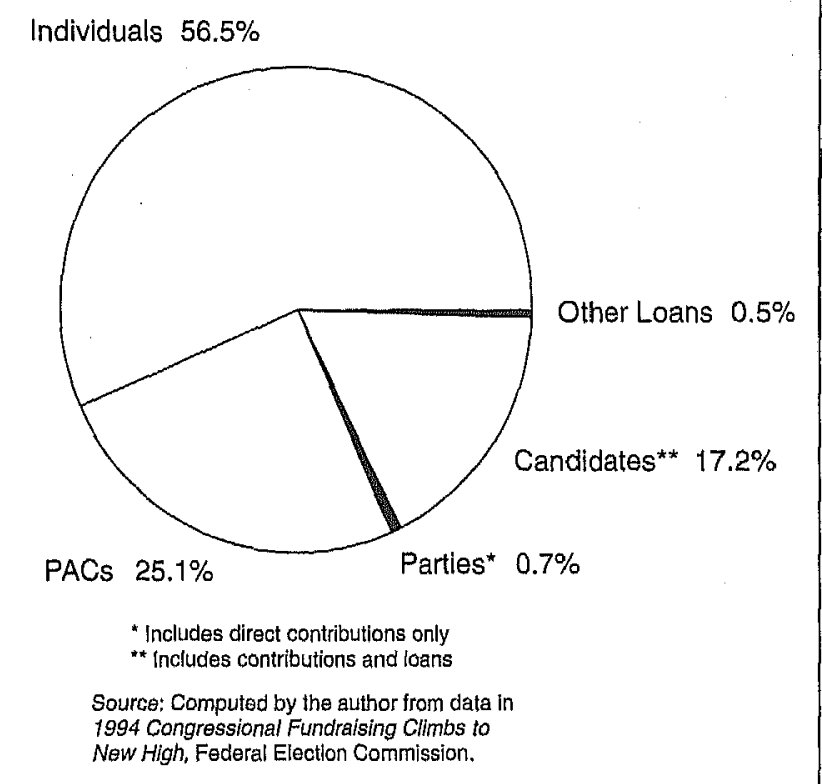

support of "party-building" activities, such as voter drives and establishing local party headquarters. ${ }^{14}$ The most generous soft money contributors in 1995 were corporations, entities that could not otherwise financially support campaigns." Dependent on corporations for much funding, parties have little incentive to finance campaign activities that meet voters' needs. Most of the parties' 1994 disbursements were for their own administrative and operating expenses, not information dissemination to voters or contributions to candidates' campaigns. ${ }^{16}$ Such spending and fund-raising tactics may make citizens feel that parties have too much influence on the political process. ${ }^{17}$

Rebuffed by PACs and receiving little from political parties and individuals, challengers must often look to their own wealth for campaign funds. While the U.S. Constitution requires only that congressional candidates be of a certain age and citizenship, leaving most citizens eligible to run, the current system of campaign finance adds an additional qualification: wealth. ${ }^{18}$ Unlike other contributors, the candidate can contribute or loan unlimited amounts of money to his or her own campaign." This option has become a necessity for challengers because today's campaigns require so much money and incumbents are favored by individual and PAC contributors. ${ }^{20}$ Self-funding of campaigns is a part of the system's wealkness, since candidates who can fund their own campaigns need not be responsive to anyone other than themselves. 
Charts 2 and 3 contrast the sources of incumbents' and challengers' contributions during the 1994 congressional campaign. Although individuals provided about one-half of these candidates' funds, individual contributions of $\$ 500$ or more provided about 30 percent and 25 percent respectively of incumbents' and challengers' funds. ${ }^{21}$ Excluded from Charts 1,2 , and 3 are the millions of dollars wealthy individuals, corporations, unions, and PACs supply in soft money and independent expenditures. Considering all sources of campaign funds, one finds the typical voter largely absent.

Voters' absence is particularly detrimental to the system because campaign financiers can influence how candidates spend contributions. Unlike their ability to raise money, candidates are largely left to their own devices when spending money. The primary restriction on campaign spending is that excess contributions may not be used to pay for personal expenses. ${ }^{22}$ The Supreme Court, equating money with speech, has determined that congressional candidates cannot be forced to restrain spending, ${ }^{23}$ Because virtually no limits exist on how much and in what manner campaign funds are spent, candidates take their cues from donors. Although some donors may offer contributions as an indication of support for a candidate's ideas, others contribute to ensure access to the winning candidate. ${ }^{24}$ Such contributions signal the importance of winning elections and gaining seniority in Congress. Therefore, candidates campaign to beat or defeat opponents, not to inform the voters. In the pursuit of victory, congressional candidates have chosen to buy advertising, campaign administration, and fund raising (see Table 2). ${ }^{25}$ These services may not always give voters, the employers of Congress, adequate information about all applicants.

Advertising can make voters and potential financiers aware of candidates but only when all candidates can afford it. ${ }^{26}$ In a 1992 nationwide poll, 62 percent of respondents stated that they often first become aware of candidates by seeing the candidates' advertisements on television. ${ }^{27}$ Therefore, candidates who advertise have a head-start in gaining attributes-such as name recognition-that appeal to donors. Since the cost of advertising is so great and contribution disparities are sometimes large, all competitors cannot advertise equally to let citizens know of their existence.

Moreover, advertising, especially the televised and "negative" variety, is relatively ineffective at informing voters about the candidates' stance on issues. ${ }^{28}$ Television advertisements have been found less effective than television newscasts at providing information on issues. ${ }^{29}$

Campaign administration expenditures also contribute little

\begin{tabular}{|c|c|c|}
\hline \multicolumn{3}{|c|}{$\begin{array}{c}\text { Table } 2 \\
\text { Distribution of Congressional } \\
\text { Campaign Expenditures, } \\
1992 \text { Campaign }\end{array}$} \\
\hline Attivity & Expenditures & $\begin{array}{l}\text { Expendifures os a } \\
\text { Percent of lotal }\end{array}$ \\
\hline Advertising & $\$ 190,317,855$ & $35 \%$ \\
\hline Administration & $130,496,023$ & 24 \\
\hline Fund raising & $84,954,183$ & 16 \\
\hline Polling & $17,085,852$ & 3 \\
\hline Donations & $11,033,171$ & 2 \\
\hline Unitemized* & $10,372,788$ & 2 \\
\hline Entertainment & $3,986,379$ & 1 \\
\hline Other*** & $94,002,523$ & 17 \\
\hline Total & $\$ 542,248,774$ & $100 \%$ \\
\hline \multicolumn{3}{|c|}{$\begin{array}{l}\text { *OHer expenditures include costs for producing } \\
\text { persuasion mail, convention fees, and food and gifts } \\
\text { for staff and volunteers. }\end{array}$} \\
\hline $\begin{array}{l}\text { Source: Co } \\
\text { and Muriell } \\
1992 \text { Cong }\end{array}$ & $\begin{array}{l}\text { y author from } \\
\text { lache, Gold-Plo } \\
\text { Races. }\end{array}$ & $\begin{array}{l}\text { wight Morris } \\
\text { d Politics: The }\end{array}$ \\
\hline
\end{tabular}

to voter knowledge and encouraging competition. ${ }^{30}$ To mount a credible campaign, a candidate must be able to buy office space, hire staff, and make fund-raising trips. ${ }^{31}$ Such expenditures bear little relation to providing information to voters and make current and potential lawmakers seem profligate.

Candidates could not operate nor promote their campaigns without money. Fund raising requires a significant amount of time and seed money, some of which could be spent informing and being responsive to the voters. ${ }^{32}$ The time and money spent on fund raising are not confined to the campaign season. Because campaigns have grown so costly, candidates are constantly trying to raise money, seeking post-election contributions to repay campaign debts. ${ }^{33}$

Year-round fund raising isolates congressional candidates from most voters. Although fund-raisers can be used to encourage more political participation, they can also be used to provide special political access to the wealthy. ${ }^{34}$ As 


\section{Chart 2: Sources of 1994 Congressional Campaign Contributions, Incumbents}

Individuals $55.3 \%$

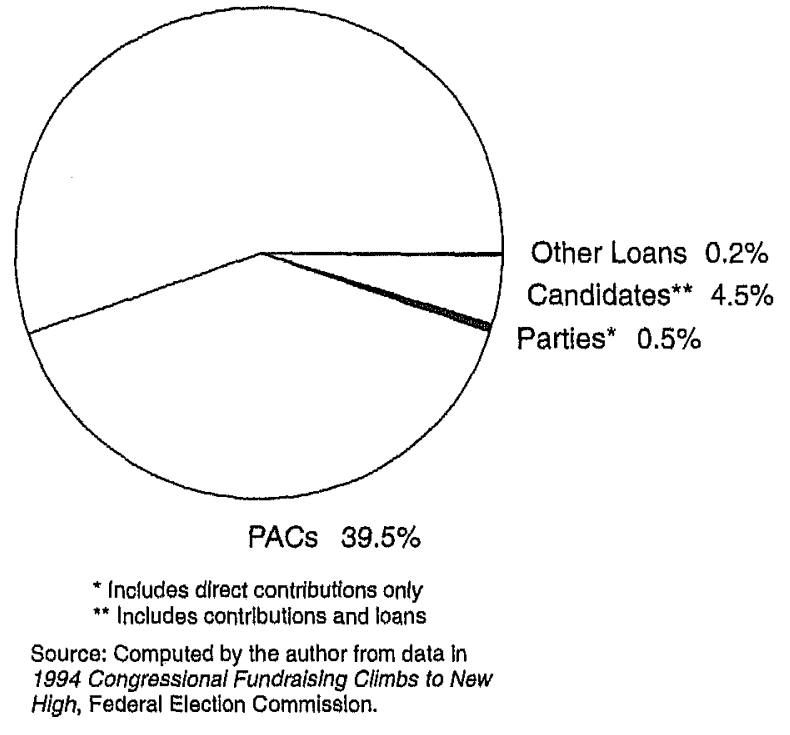

a result, candidates may receive more information from individuals or groups with more narrow interests than the typical voter. ${ }^{35}$ One columnist quoted a political party official saying to a potential donor, "If you don't give money, you're just a voter. ${ }^{36}$

Such comments and the public's pervasive disrespect for and distrust of congressional candidates are a function of the time and money spent on fund raising. Senator Dianne Feinstein (D-CA) expressed this link saying, "The fund-raising pressure on candidates is so enormous. When you couple that with increasing negativity of campaigns, the result is an upsurge in public cynicism." ${ }^{37}$

Although cynicism alone is likely to prevent many citizens from considering a run for Congress, the additional requirement of personal wealth that today's system places on candidates may discourage many more and makes Congress less representative. One year before the 1994 election; challengers had not emerged in eleven of the twenty-six Senate races with an incumbent candidate. ${ }^{38}$ At that time, incumbents had raised more than three times as much as challengers in 1993 and had more than seven times as much money left for campaigning in $1994 .{ }^{39}$ When challengers did emerge, they were often supported by their own wealth. ${ }^{\text {in }}$ The Senate's twenty-eight millionaires are more representative of winning candidates than American voters. ${ }^{41}$

When members of Congress are not truly representative of

\section{Chart 3: Sources of 1994 Congressional Campaign Contributions, Challengers}

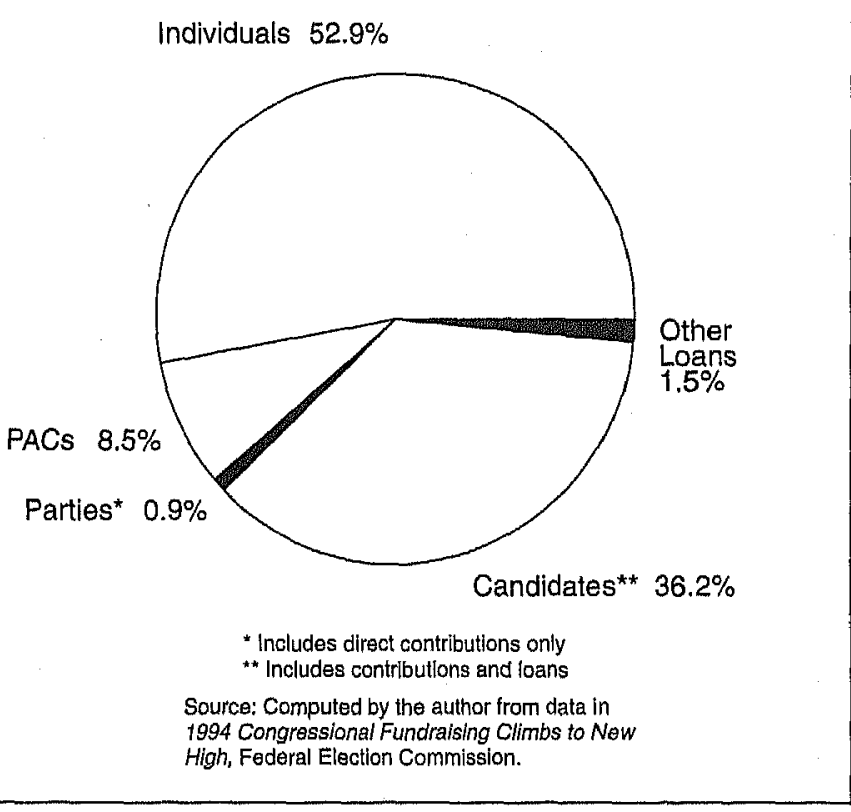

the public they serve, voters are not likely to seek or find information about congressional candidates. Disillusioned voters may ignore media coverage of campaigns and elections. Those voters who continue to follow media covernge of campaigns may notice that all candidates do not receive equal coverage, and that all candidates may not be invited to privately-sponsored debates. ${ }^{42}$ Therefore, neither political advertisements nor the media are likely to provide voters with the information needed to have and make a choice.

Because campaigns are financed largely by wealthy individuals and PACs, candidates spend funds to fulfill the financiers' desires and ignore those who have been shut out of the campaign financing system-the voters. A winning campaign requires spending on advertising, campaign administration, and fund raising, but these expenditures do not fulfill the needs of voters for informative and competitive campaigns. Therefore, today's system of funding congressional campaigns must be reformed if voters' needs are to be met.

\section{Analysis of Policy Alternatives}

Despite abundant weaknesses, today's system of congressional campaign finance conveys some benefits to voters. Allowing individuals to contribute to campaigns directly, or indirectly through PACs and parties, gives voters an opportunity to provide additional support to the candidate of their choice. Advertising can increase voter awareness and 
interest, and fund raising and campaign administration permit candidates to convey their messages. Unlimited spending on campaigns protects candidates' rights to free speech.

However, these benefits do not justify maintaining the status quo. The current system of congressional campaign finance is deficient in what it provides and in what it lacks. The system showers voters with a barrage of generally uninformative advertising and the message that "contributions buy access." The system does not adequately familiarize voters with issues and candidates' stances and does not promote competitive races. Whether and to what extent these deficiencies can be corrected depends on the voters' willingness to pay.

Several proposals have been offered to reform the current system of campaign finance. Two proposals, one sponsored by several members of the 104th Congress and another praised by the Speaker of the House of Representatives, Newt Gingrich (R-GA), would cost voters nothing and are not likely to affect how candiclates spend campaign funds. Consequently, neither of these proposals is likely to significantly increase the level of competition and information in todlay's campaigns nor enhance citizens' perception of their government. Another alternative, public financing, would reduce the need to raise funds, and thus, would encourage more competitive races and lessen the influence of some campaign contributors compared to that of voters. However, full public financing carries a price tag that many voters, accustomed to free campaigns and uncontrolled candidate spending and speech, may not want to bear. In contrast, the Voter Information Program (VIP) is affordable because it targets only the need for information and competition and does not require candidates to relinquish their rights to free speech.

\section{H.R. 2566 and S. 1219}

The most recent legislative proposals for congressional campaign finance reform are H.R. 2566 "The Bipartisan Clean Congress Act of 1995," and S. 1219, "The Senate Campaign Finance Reform Act of 1995." Sponsors of these bills assume that candidates and parties have to spend too much on campaigns and receive too much money from non-constituents, but find little fault with how money is spent. These bills:

- establish voluntary spending limits (\$600,000 for House races and between $\$ 1.5$ and $\$ 8.1$ million for Senate races depending on the size of a state's voting age population). These limits include restrictions on how much candidates can spend from their own wealth.

Candidates complying with spending limits receive free or discounted broadcast time and reduced postage rates. ${ }^{43}$ If a candidate does not adhere to spending limits, the opponent's limit on individual contributions is doubled to $\$ 2,000$, thus raising the opponent's limit on spending. ${ }^{4 i}$

- ban contributions from PACS. If the ban is ruled unconstitutional, PAC contribution limits will be lowered to $\$ 1,000$, and candidates will be prohibited from raising more than 20 or 25 percent of their funds from PACs.

- require candidates to raise 60 percent of campaign funds from individuals within the candidate's state.

- limit or ban soft money and the bundling of contributions. ${ }^{\text {is }}$

The House bill would also limit individual contributions of $\$ 250$ or more to $\$ 150,000$ and contributions from lobbyists to $\$ 100$, and allow an opponent to match any independent expenditures totaling $\$ 25,000$ or more without violating spending limits. ${ }^{46}$ Although these bills are gaining the support of members of Congress and the public, the bills' major provisions are unlikely to encourage much more information and competition in campaigns, and may even discourage these ideals. ${ }^{17}$

Spending limits are one of the riskiest means of encouraging adequate competition-and have been tried before without success. Congressional candidate spending was restricted from the early 1900 s until $1976 .{ }^{\text {th }}$ For most of this period, spending restrictions were more akin to a traffic cone than a roadblock; candidates could maneuver around the vague limits with ease. ${ }^{19}$ When restrictions were tightened in 1974, candidates complained, and the Supreme Court held, that spending limits amounted to an unconstitutional restraint on free speech. The Court made one exception: limits could be imposed on candidates voluntarily accepting campaign funds from the government. ${ }^{50}$ Since then, spending limits have generally been proposed in conjunction with public financing. The court has not considered whether spending limits could be imposed on candidates who accept free time on the public airwaves.

Even if constitutional, spending limits are unlikely to consistently encourage competition or wide dissemination of information to voters. Effective limits would be extremely difficult to set for two reasons. First, the varying and rising cost of advertising in different media markets must be considered. Second, candidates must be able to spend enough to effectively campaign but not so much that challengers are discouraged from running. In the 1994 election, median 
spending by losing House challengers in the closest races was $\$ 340,000$, well below H.R. 2566's limit. ${ }^{51}$ The median spending of winning incumbents hovered near $\$ 600,000$ in the most competitive races. ${ }^{52}$ Therefore, H.R. 2566's spending limits may go unnoticed by many challengers and some incumbents. Those candidates who foresee reaching the limit may target their campaign message to certain voters by ignoring unregistered or disenchanted voters. ${ }^{53}$ Indirect spending, such as independent expenditures, could also rise; a bidding war could start if candidates match independent expenditures made by an opponent's supporters. Since candidates are generally less accountable for this type of spending, the quality of communication with the voters could decline.

\section{Spending limits are one of the riskiest means of encouraging adequate competition-and have been tried before without success.}

Rewarding candidates who abide by spending limits with discounted media and mailings may reduce campaign costs and equalize the media exposure of incumbents and challengers, but overwhelm the airwaves without providing more information about all candidates, H.R. 2566 and S. 1219 fail to recognize that, due to the varying reach of media markets, some television stations may not be able to logistically or financially accommodate television time for all congressional candidates, much less state and local candidates. For example, New York City's stations would have to provide one-half hour of free air-time and an unlimited. amount of paid time to sixty-six congressional candidates. ${ }^{54}$ State and local candidates would continue to be pre-empted, and the public would be unlikely to tune in to so much political programming. ${ }^{55}$ The public is also not apt to retain much from seeing candidates on television. Research indicates that viewers are likely to recall less from television than newspapers. ${ }^{56}$

Broadcasters are likely to seek the public's help in opposing discounted media for congressional campaigns. Supporters of discounted media argue that television and radio broadcasters must obtain a license that requires operation in the public trust; providing free air time to candidates is an extension of the licensing agreement." Broadcasters contend that this mandate would be an unconstitutional taking of property. ${ }^{54}$ Proponents claim that the United States is the only major democracy that does not provide free media access for candidates. ${ }^{59}$ However, many of the governments that provide free media time also limit or ban political advertising, and Great Britain gives the time to parties rather than candidates. ${ }^{\text {(in }}$ Even if broadcasters cannot sway the Supreme Court to join them in opposition, voters are likely to oppose free mediat time. Although a link between spending limits and discounted media was not made, a recent poll found that 64 percent of Americans do not think politicians should get free TV time.

Although politically popular, banning PACs is probably unconstitutional, and limiting PAC contributions may unintentionally reduce competition and voter participation. Outlawing PACs might challenge an individual's First Amendment right to free association. ${ }^{62}$ While reducing PAC contribution limits is more likely to be constitutional, this would do little to dilute PAC influence. Most PACs contribute much less than present limits and would simply find other, less accountable means to contribute, such as independent expenditures or increased lobbying, or would share their wealth and influence with more candidates. ${ }^{6.3}$ PACs most often bankroll incumbents, but they have jumped on the challenger's bandwagon in some competitive races. ${ }^{\text {(1) }}$ Therefore, limiting PAC contributions could mean the difference between a close race and a challenger's victory. PACs can also provide an opportunity for citizens to become easily involved and interested in campaigns and are efficient fund-raisers.

Like PAC limits, restricting the amount candidates can receive from those outside the voting clistrict is intended to increase the influence of a candidate's voting constituents over purely financial constituents. However, this proposal has political and logistical challenges. This reform might disadvantage poor or minority candidates who often depend on national advocacy organizations for contributions. ${ }^{65}$ H.R. 2566 and S. 1219 fail to acknowledge that, in today's complex society, local interests are national and vice-versa. In addition, localizing contributions would increase candidates' administrative costs and require the Federal Election Commission (FEC) to check the residency status of individual contributors in addition to monitoring candidate compliance with spending limits.

Finally, although outlawing soft money would plug one drain filled with unregulated spending, it may reduce spending on soft money's beneficial activities, such as voter drives. Banning soft money may also encourage its contributors, who cannot legally contribute to campaigns any other way, to seek new and potentially more harmful ways. to influence campaigns.

The major provisions of H.R. 2566 and S. 1219-spending 
limits, discounted media, and further restrictions on PACs and other contributors-would make few changes in who finances campaigns and how that money is spent. As a result, these bills are unlikely to significantly enhance the amount of information voters receive in campaigns or the competitiveness of campaigns. Consequently, voters are unlikely to agree that real reform has occurred and more likely to become disinterested in campaigns and government.

\section{Speaker Gingrich's Proposal}

Denouncing H.R. 2566's and S. 1219's premise that too much money is spent on campaigns, opponents of these bills, such as House Speaker Newt Gingrich (R-GA), argue that candidates do not spend enough on campaigns. Current campaign spending amounts to 0.05 percent of gross national product. ${ }^{66}$ Increased spending on campaigns has been linked to increased voter interest and turnout and success for challengers. ${ }^{67}$ Gingrich argues that these benefits of candidate spending are limited by today's anachronistic contribution limits. The value of the $\$ 1,000$ individual contribution limit imposed in $\mathbf{1 9 7 4}$ has decreased by more than half. ${ }^{6}$ Therefore, contributors are tempted to find ways to circumvent these limits, and candidates must approach many individuals to raise funds. Gingrich suggests raising an individual's contribution limit to $\$ 5,000$ and indexing contribution limits for inflation. ${ }^{69}$

\section{Although politically popular, banning PACs is probably unconstitutional...}

Although raising contribution limits may encourage more direct contributions and make fund raising less obtrusive, such reforms may increase total spending and the influence of certain contributors without any corresponding increase in information or competition. Raising contribution limits is likely to fuel growth in campaign spending without providing candidates any incentive to spend more thoughtfully. ${ }^{70}$ Depending on how new limits are set and indexed, candidates, especially incumbents, might be able to raise more money from fewer contributors. Higher contribution limits are also likely to heighten incumbents' fund-raising advantages. ${ }^{71}$ Although efficient, such fund raising and its potentially corrupting influence are what the existing contribution limits intended to stop.

Political infighting could also ground this reform. Higher individual and party contribution limits would primarily benefit Republicans, whose constituents and national orga- nization are more likely to make higher contributions. ${ }^{72}$ Possibly because over 80 percent of Americans have indicated support for limiting congressional campaign spending, an increase in contribution limits has not been included in recent legislation, despite Republican control of Congress. ${ }^{73}$

Like H.R. 2566 and S. 1219, increasing contribution limits attempts to reform the current system of campaign finance at no cost to voters. But allowing current contributors to pump more money into the system does not necessarily mean more information and competition will emerge. Without incentives to redirect the increased contributions toward informing voters, candidates are likely to simply continue the spending and fund-raising practices that presently distance them from the voters.

If citizens believe that private financiers will not support the public interest, citizens must decide what they desire from congressional campaigns and how much they will pay. Two reforms, public financing and the Voter Information Program (VIP), illustrate the range of problems voters can address for a given price.

\section{Public Financing}

Traditional public financing programs call for the federal government to provide all or some of a candidate's funds. As in U.S. presidential primary campaigns, public funds could be distributed in proportion to the amount raised from all or a subset of contributors. ${ }^{74}$ Such a matching fund system permits individuals and PACs to continue active participation in the political process. Or, as in U.S. general election campaigns for President, a candidate could receive a fixed amount of public funds only by refusing to accept any private contributions. ${ }^{75}$ Such an exchange might reduce the perceived influence of any contributor but organized contributors, such as PACs and political parties, would still have independent expenditures and soft money at their disposal.

Public financing at the presidential level has a track record of giving candidates the seed money needed to campaign effectively while mitigating $\mathrm{PAC}$ influence and reducing fund-raising time and costs. Since 1976, U.S. presidential campaigns have been funded by taxpayers who designate a portion of their tax dollars to a presidential election campaign fund (a check-off system) ${ }^{76}$ Recent presidential elections have been more competitive than congressional races; challengers have won three of the last five contests." Presidential candidate, Walter Mondale, praised public financing for allowing him to concentrate and remain firm 
on policy issues. ${ }^{78}$ Presidential public financing has also preserved candidates' rights to free speech by limiting the amount rather than the type of campaign spending.

Ironically, the preservation of candidates' speech at the taxpayers' expense is public financing's fatal flaw. Because traditional public financing proposals often place generous limits on how much candidates can spend and no limits on what candidates buy, these programs are prohibitively costly and unlikely to increase the amount of information voters receive in campaigns. Estimates of the government's payment to candidates under a public financing scheme depend on whether grants are fixed or matched and whether spending limits are set. Legislation mandating public financing of congressional campaigns with spending limits for House and Senate candidates would have required government outlays of $\$ 259$ million in $1988 .^{79}$ Public financing would also likely increase the government's cost to regulate campaigns. Instead of monitoring and providing funds to a few presidential candidates, the government would have to provide funds to and monitor the spending of hundreds more congressional candidates.

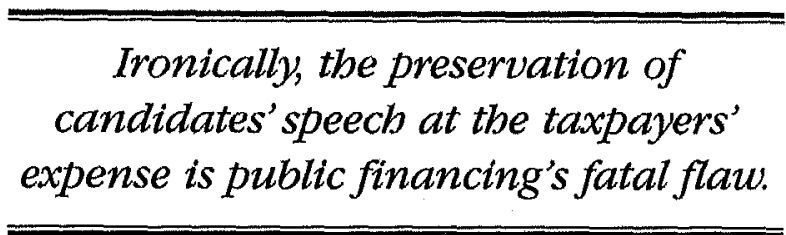

Moreover, public financing has not necessarily led to more informative campaigns. One primary source of information about the presidential candidates, debates, is not paid for with the candidates' public funds. A non-profit commission, using contributions from corporations and foundations, sponsors presidential debates. ${ }^{80}$ This allows presidential candidates to spend their funds on many of the same items as congressional candidates. ${ }^{81}$ Therefore, traditional public financing can be viewed as a "take the money and run" reform; candidates are given public dollars to finance any aspect of the campaign, regardless of citizens' desires. Since candidates presently do not spend private money on them, voters are rightly reluctant to contribute tax dollars to support campaigns.

\section{The Voter Information Program (VIP)}

In contrast to public financing, VIP would "take the money and inform." Rather than distribute taxpayer funds to freespending candidates, the government would use taxpayer funds to publish voters' guides and sponsor debates. Although a few states currently provide these services, this proposal would extend and standardize these practices across the United States to give citizens more information and provide non-wealthy challengers with the seeds of a campaign. ${ }^{82}$

To effectively and efficiently implement VIP, Congress should fund and produce voters' guides and states should fund and produce debates. Voters' guides should be financed through additional appropriations to the Federal Election Commission (FEC) because the check-off system that finances presidential elections is so widely misunderstood and under-funded that adequate support for another system would not likely be attained. ${ }^{\text {Bz }}$ Congress can and should be trusted to appropriate funds for voters' guides because the guides, like other appropriated legislative branch services, are needed for the effective operation of Congress.

Information for the guides could be easily submitted to the FEC along with current filing requirements. The voters' guides would contain candidates' biographies, a brief statement of positions on government's missions, and a message to voters on any other issues of the candidate's choice (e.g., states' rights, moral issues). ${ }^{\text {s. }}$ The guides would also contain the time and place of candidate debates.

Newspaper-style guides could be printed for each state or district, depending on expense, and would be mailed to every registered voter.

States would fund and organize debates for each House and Senate race that would address issues of interest and allow citizens to submit questions. To keep costs low, the debates could be televised on public broadcasting stations or locally-operated cable stations. Transcripts of the debates would be published the next day in the jurisdiction's two largest newspapers if a public station is not available or inaccessible to some voters.

VIP would give voters what they want. In a recent poll, 93 percent of respondents agreed that representatives should try to keep voters informed of issues through frequent visits or newsletters. ${ }^{85}$ Supplementing political advertising with debates and guides informs voters while respecting candidates' rights to free speech. Debates contribute more to voter knowledge of candidates' positions on issues than the news media and advertisements. ${ }^{86}$ Debates are also likely to increase the competitiveness of races. One study indicates that debates may be most useful to candidates with little name recognition and small budgets because even relatively uninformed viewers were able to identify candidates and parties after a debate. ${ }^{87}$ VIP ensures that information about a challenger reaches every voter regardless of a challenger's resources. Informing citzens removes an impediment to voting and could mitigate the public's cynicism for the political process. 
VIP would likely be less costly than its traditional counterpart because informational activities have proven to be relatively inexpensive. For example, the state of Oregon prepares voters' guides that contain uniform information, such as occupation and educational background, about each candidate for federal and state office as well as candidates' statements and arguments related to ballot issues. ${ }^{88}$ Guides for Oregon's most recent primary and general elections cost about $\$ 1.7$ million to produce and were mailed to each household. Because a traditional public financing system would fund all or some portion of the $\$ 724$ million congressional candidates spent in the 1994 campaign, VIP is likely to cost hundreds of millions of dollars less than public financing programs. ${ }^{\text {. }}$

\section{VIP ensures that information about a challenger reaches every voter regardless of a challenger's resources. Informing citizens removes an impediment to voting and could mitigate the public's cynicism for the political process.}

Supplementing rather than replacing the current system of campaign finance, VP allows candidates to maintain their relative freedom to raise and spend money. Although VIP may provide candidates with less incentive than some reforms to organize prize-winning fund raisers and to seek contributions from non-voting constituents, these activities are likely to continue. Neither VIP nor any reform short of outlawing fund raising will stop these practices. However, outlawing fund raising would require taxpayers to fund all campaign expenses, including those that yield no benefits to voters. Therefore, diligent news media and citizen activists are the best defense against undemocratic fundraising tactics while VIP attacks the information and competition voids.

\section{Conclusion}

The problem with and the solution to today's system of congressional campaign finance lies in the answer to the question, "who pays and how much?" Today's system is not financed by voters; therefore, voters benefit little from the predominant campaign expenditures of advertising, campaign administration, and fund raising. If voters want more information and competition in campaigns, and consequently more reason to participate in elections, they must pay for these benefits.

Reform proposals offered by members of the 104th Congress are unlikely to significantly increase the level of information or competition in today's campaigns because the proposals do not significantly change the financiers or the purpose of campaign expense. Traditional public financing changes the financiers but not the purpose of campaign expense. None of these proposals will respond to the pleas of citizens like Mary Mann, a potential voter in the 1996 Republican presidential primary in New Hampshire, who said "I wish I heard more from the candidates] about what they would do ... You hear the ads, you read the papers and watch TV, but you don't understand exactly what they'll do. I think a lot of voters are frustrated. We're trying to make a decision, but I don't know if we have enough information to do it." ${ }^{\text {,91 }}$ Only the Voter Information Program lets voters pay for what they want-more information and competition-and subsequently, a more responsive government. $\star$

\section{Notes}

${ }^{{ }^{I}}$ wish to thank my editor, Julie Kotzin, for encouraging me to continuously refine this article and always thinking of something I had not. I also appreciate the many efforts of my associate editor, Michael Krauthamer, to ensure the accuracy and clarity of this article. Heather Johnston, editor in chief, eagerly provided resources and suggestions that were invaluable to this article. Finally, I would like to thank Professor Jill Kasle, faculty advisor, for convincing and helping me to write about a subject for which I care deeply.

The views expressed in this article are those of the author and do not represent the policy or position of the U.S. General Accounting Office.

${ }^{1}$ Ruy A Teixeira, The Disappearing American Voter
(Washington, D.C.: The Brookings Institution, 1992), 6.

${ }^{2} I$ Ibid, 47.

${ }^{3}$ The typical voter is a citizen who is qualified to vote and earns the median U.S. income.

"Ruth S. Jones, "Contributing as Participation," in Money, Elections, and Democracy: Reforming Congressional Campaign Finance, edited by Margaret Latus Nugent and John R. Johannes (Boulder, Co.: Westview Press, 1990), 29.

"The 11 million citizens of San Diego made only half as many campaign contributions as the 31,000 residents of Beverly Hills. Although individuals provided about half of the $\$ 740$ million directly contributed to candiclates' 1994 campaigns, half of those contributions were made in amounts of $\$ 500$ or 
more. (Michael Lind, "Me and Mrs. Smith," The New Republic, 5 February 1996, 16; Federal Election Commission, 1994 Congressional Fundraising Climbs to New Higb [Washington, D.C., 28 April 1995], 4, 10.)

${ }^{6}$ Federal Election Commission (FEC) regulations define a PAC as a multicandidate committee that has received contributions from more than fifty contributors, has been registered with the FEC for at least six months, and has contributed to at least five federal candidates Prohibited by FECA and prior laws from contributing directly to campaigns, corporations and trade unions formed PACs as a means of leveraging the resources of their members to exert collective influence over the political process. Relatively few PACs existed in 1974, the year FECA's current limits were established to reduce the influence of wealthy individual donors. Between 1974 and 1984, the number of PACs grew from about 600 to nearly 4,000. Although PACs are financed by citizens, wealthier citizens tend to contribute more. The 1981-82 average donation to a PAC was $\$ 100$, which is equal to $\$ 150$ today. (FEC, 1994 Congressional Fundraising, 4; Federal Election Commission, Campaign Gutde for Congressional Candidates and Committees [Washington, D.C., December 1995], 6; Philip M. Stern, The Best Congress Money Can Buy [New York: Pantheon Books, 1988], 9; David B. Magleby and Candice J. Nelson, The Money, Chase: Congressional Campaign Finance Reform [Washington, D.C.: The Brookings Institution, 1990], 13-14, 18; Federal Election Commission, Twenty Year Report [Washington, D.C., 1995], 29; Larry J. Sabato, PAC Power: Inside the World of Political Action Committees [New York: W.W. Norton \& Company, 1984], 59). The real value of the average 1981-82 PAC donation was calculated using the consumer price index.

${ }^{7}$ An independent expenditure is advocacy spending without the candidate's authorization. This type of spending allows PACs to influence congressional campaigns without directly contributing to them. Although small compared to direct contributions, independent expenditures are influential because they are usually concentrated in a few races and are unlimited. Independent expenditures for the 1994 campaign totaled $\$ 4.6$ million. (Magleby and Nelson, 19-20; FEC, Campaign Guide, 18; Stern, 165, 167; Candice J. Nelson, "Loose Cannons," in Money, Elections, and Democracy: Reforming Congressional Campaign Finance, edited by Margaret Latus Nugent and John R. Johannes (Boulder, Colo.: Westview Press, 1990], 48-50; FEC, 1994 Congressional Fundraising, 15.)

${ }^{8}$ An August 1995 survey indicated that more than 90 percent. of registered voters believe PAC contributions influence the votes of members of Congress. Nearly 70 percent of Americans worry that those who contribute large amounts receive special favors from the candidates. (Ann McBricle, "Don't Give Up on Washington," Social Policy 26, no, 1 [fall 1995]: 15; Common Cause, Editorial Memorandum: Congress Achieves Major Breaktbrough on Campaign Finance Reform; Bipartisan Legislation Sets Stage for Reform Action [Washington D.C.: Common Cause, September 1995], 9.)

${ }^{9}$ During the 1994 campaign, PACs contributed seven times as much to incumbents as challengers. (FEC, Twenty Year Report,
29; FEC, 1994 Congressional Fundraising, 4.)

${ }^{10}$ The political parties supplied $\$ 5$ million dollars, or less than 1 percent, of candidates' direct contributions in the $1994 \mathrm{cam}$ paign and split their contributions roughly equally between incumbents, challengers, and candidates in open seat races. (FEC, 1994 Congressional Fundraising, 4.)

${ }^{11}$ Magleby and Nelson, 103.

${ }^{12}$ Coordinated expenditures for the 1994 campaign totaled \$414 million. (FEC, Campaign Guide, 16; FEC, 1994

Congressional Fundraising, 5.)

${ }^{13} \mathrm{FEC}$, Twenty Year Report, 19.

${ }^{14}$ During 1994, the Democratic and Republican National Committees collected nearly $\$ 100$ million, or half or more of each committee's funds, in soft money receipts. (Stern, 163; FEC, Twenly Year Report, 19, 21.)

${ }^{15}$ Charles R Babcock, "Parties Raised Nearly $\$ 60$ Million in 'Soft' 1995 Donations," The Washington Post, 11 March 1996, A17.

${ }^{16}$ FEC, Twenty Year Report, 21.

${ }^{17}$ Eighty percent of respondents to a recent national poll agreed that political parties have "too much influence on Washington." (Institute for Social Research, University of North Carolina, national telephone survey, Chapel Hill, N.C., 17 November 1994, Polling the Nations CD-ROM.)

${ }^{18}$ US, Constitution, art, 1, sec, 2-3.

${ }^{19}$ In 1976, the Supreme Court invalidated caps on candidates' contributions to their own campaigns while upholding limits on the amounts individuals, PACs, and parties could contribute to campaigns. The Court reasoned that contributions from the candidate could offset any adverse influence of contributions from wealthy donors. (Buckley v. Valeo, 424 U.S. 58 [1976].)

${ }^{20}$ Campaign workers state that House challengers are expected to contribute at least $\$ 25,000$ to their own campaigns while Senate challengers loan themselves even more. (FEC, 1994 Congressional Fundraising, 5; Magleby and Nelson, 45.)

${ }^{21} \mathrm{FEC}, 1994$ Congressional Fundraising, 10.

${ }^{22}$ Lawmakers have determined that candidates are generally best able to determine whether a particular expenditure will advance their campaigns. (FEC, Twenty Year Report, 22; Robert F Bauer and Doris M. Kafka, United States Federal Election Law. [Dobbs Ferry, N.Y.: Oceana Publications, 1984], 55.)

${ }^{23}$ Buckley v. Valeo, 424 U.S. 58.

${ }^{2:} \mathrm{PACs}$ often make significant campaign contributions outside the election cycle, and in close races, PACs have conttibuted to both candidates. Similarly, the most generous soft money contributors in 1995 gave to both the Democratic and Republican National Committees. (Sabato, 90; FEC, Twenty Year Report, 28; Babcock, "Soft' 1995 Donations," A17.)

${ }^{25}$ Data on the composition of candidates' spending in the 1994 campaign was not available. 
${ }^{26}$ The bulk of advertising expenditures in the 1992 campaign was spent on television commercials, One campaign official estimated that $\$ 90,000$ allows the average television viewer to see a candidate's commercial five times a week. This rate reflects a federal requirement that television stations must sell air time to any requesting federal candidate at their lowest rate. Stations must sell an equal amount of time at the same rate to any requesting opponent. (Dwight Morris and Murielle E. Gamache, Gold- Plated Politics: The 1992 Congressional Races, [Washington, D.C.: Congressional Quarterly, 1994], 2223, 28-29; Gregg Zoroya, "Suburban Candidates Find Some Broadcast TV Stations Don't Want Their Business," The Washington Post, 11 September 1994, B5; Federal Election Commission, Federal Election Campaign Laws, [Washington, D.C., June 1994], 107-8.)

${ }^{27}$ Times-Mirror for the People $\&$ the Press, national telephone survey, Washington, DC., July 8, 1992, (Polling the Nations) CD-ROM.

${ }^{28}$ After California Senate candidate Michael Huffington spent $\$ 9$ million in 1994 on largely negative advertising, only half of the state's voters said they knew enough about Huffington to have an opinion about him. Forty-eight percent of New Jersey residents said they learned "not much" or "nothing" from the 1992 presidential candidates' political advertisements. Seventy percent of U.S. voters said these advertisements had not provided any new information about the candidates. Despite record spending in the 1994 Virginia Senate race, two out of three voters were completely unaware of candidates' positions on issues those voters considered important. (Howard Kurtz, "Slash Attacks Remain A Big Hit in Televised Advertising," The Wasbington Post, 26 September 1994, A7; Eagleton Institute of Politics, a telephone survey of likely voters in New Jersey, New Brunswick, N.J., 25 October 1992, Polling the Nations CD-ROM; The New York Times, national telephone survey, New York, N.Y., 23 October 1992, Polling the Nations CDROM; Richard Morin, "You Think the Congress is Out of Touch? Look in the Mirror, Voters, the Trouble Starts with You," The Washington Post, 16 October 1994, C1.)

${ }^{29}$ Xinshu Zhao and Steven H Chaffee, "Campaign Advertisements Versus Television News as Sources of Political Issue Information," Public Opinion Quarterly 59, no. 1 [spring 1995]: 51.

${ }^{30} \mathrm{Administration}$ spending reflects the declining influence of political parties on candidates' campaigns. Individuals and PACs now pay for the candidates to administer campaigns, where political parties previously had provided these services directly to candidates. (Morris and Gamache, 36.)

${ }^{31}$ Ibid., 36-37.

${ }^{32}$ One lawmaker recently claimed attendance at ten fund raisers in a single day while another lawmaker characterized the amount of time spent on raising money as "inordinate" In a 1988 survey, 52 percent of Senators and 73 percent of Senate staff agreed that fund raising demands significantly reduced time spent law-making. (Phil Kuntz, "The Money Chase: A Day in Washington Is Just Another Day to Raise More Dollars," The Wall Street Journal, 23 October 1995, A1; Martin
Schram, "Shakedown," Mother Jones, September 1994, 28; Magleby and Nelson, 44.)

${ }^{33}$ Magleby and Nelson, 59

${ }^{34} \mathrm{~A}$ recent Republican party fund-raising dinner brought in a record $\$ 16$ million. Donors who gave $\$ 250,000$ or more received a private lunch with the Speaker of the House and the Senate Majority Leader. (Martin Dyckman, "A Test of Money's Grip," St. Petersburg (Fla.) Times, 1 February 1996, 15A.)

${ }^{35}$ Ross Clayton Mulford, "Laws Must Be Nonpartisan Not Bipartisan," Social Policy 26, no 1 (fall 1995): 13.

${ }^{36}$ Charles Lewis, "Money: No Minor Matter in Politics," The Wasbington Post, 12 February 1996, A19.

${ }^{37}$ Faye Fiore, "Feinstein Critics Assail Election Reform Stance," The Los Angeles Times, 17 September 1995, A28.

${ }^{38}$ Charles R. Babcock, "Money, the Senate and Running for Election," The Washington Post, 7 March 1994, A17.

${ }^{39}$ Ibid.

${ }^{40}$ Challengers financed 36 percent of their 1994 congressional campaigns; incumbents financed only 5 percent of their 1994 campaigns. (See Charts 2 and 3.)

"David S. Broder, "A Senate of Millionaires," The Washington Post, 17 January 1996, A17.

"Dan Balz and Thomas B. Edsall, "Rivals Take Aim in Carolina Debate," The Washington Post, 1 March 1996, A8.

${ }^{13}$ The House bill also stipulates that a candidate must agree to limit his or her own contribution to the campaign to 10 percent of the spending limit. (Office of Representative Linda Smith, Section-by-Section Summary of H.R. 2566, The Bipartisan Clean Congress Act of 1995, [Washington, D.C., January 1996], 2-4.)

${ }^{44}$ Office of Representative Linda Smith, Section-by-Section Summary of HR. 2566, 2-4; Office of Senator John McCain, Overview of McCain/Feingold/Thompson Campaign Finance Reform Bill, (Washington, D.C., January 1996), 2.

${ }^{45}$ Office of Representative Linda Smith, The Bipartisan Clean Congress Act of 1995, HR. 2566, Short Summary, (Washington, D.C., January 1996), 1; Office of Senator John McCain, Overview of Campaign Finance Reform Bill, 1-4.

${ }^{46}$ For example, a candidate could not receive more than one individual contribution in the amount of $\$ 150,000$ or more. (Office of Representative Linda Smith, Section-by-Section Summary of H.R. 2566, 2, 4.)

${ }^{47}$ Office of Representative Linda Smith, Sponsors of HR. 2566, (Washington, D.C.: January 1996), 1; Ellen Weir, "Building Pressure for Campaign Finance Reform," The National Voter, March/April 1996, 2.

\footnotetext{
${ }^{18} \mathrm{FEC}$, Twenty Year Report, 2-3.
}

${ }^{40}$ Margaret Latus Nugent and John R Johannes, "Introduction: What Is at Stake?" in Money, Elections, and Democracy: 
Reforming Congressional Campaign Finance, edited by Margaret Latus Nugent and John R. Johannes (Boulder, Colo.: Westview Press, 1990), 3.

${ }^{50}$ Buckley v. Valeo, 424 U.S. 109.

${ }^{51}$ FEC, 1994 Congressional Fundraising, 12.

${ }^{52} \mathrm{Ibid}$.

${ }^{53}$ Thomas N Edmonds, "Campaign Finance Reform: Let the People Do the Talking," The Washington Post, 26 February 1994, A23.

${ }^{54} \mathrm{~J}$ on R. Sinclair, "Reforming Television's Role in American Political Campaigns: Rationale for the Elimination of Paid Political Advertisements," Communications and the Law 17, no. 1 (March 1995): 88.

${ }^{55}$ Zoroya, B5.

${ }^{56}$ Sinclair, 78 .

${ }^{57}$ Ibid., 82-83.

${ }^{58}$ Sinclair, 89.

${ }^{59}$ Steven. Hill, "For Campaign Finance Laws That Work, Look Abroad," The Cbristian Science Monitor, 28 February 1995, 19.

${ }^{60}$ Sinclair, 84.

${ }^{61}$ Yankelovich Partners, Inc, national telephone survey, Washington, D.C., October 22, 1990, Polling the Nations CDROM.

${ }^{62}$ Magleby and Nelson, 147.

${ }^{63}$ Ibid, , 148-50,

${ }^{64}$ Sabato, 77.

${ }^{65} \mathrm{FEC}$, Twenty Year Report, 28.

${ }^{66} \mathrm{~B}$. Smith, A14.

${ }^{67}$ Ibid.

${ }^{68} \mathrm{FEC}$, Twenty Year Report, 32.

${ }^{69}$ David S. Broder, "Gingrich's Heresy," The Washington Post, 14 November 1995, A19.

${ }^{70}$ Magleby and Nelson, 143.

${ }^{71}$ Ibid., 144.

${ }^{72} I$ bid., 57 and 111 ,

${ }^{75}$ Common Cause, 1.
${ }^{74}$ Magleby and Nelson, 154-55.

${ }^{75} \mathrm{Ibid}$.

${ }^{76}$ Anthony Corrado, Paying for Presidents: Public Financing in National Elections (New York: The Twentieth Century Fund Press, 1993), 2.

7"David S Broder, "Competitive Politics Costs," The Washington Post, 23 June 1993, A17.

${ }^{78}$ Stern, 198.

${ }^{79}$ Magleby and Nelson, 159.

${ }^{80}$ Herbert E. Alexander and Monica Bauer, Financing the 1988 Election, (Boulder, Colo.,: Westview Press, 1991), 95.

${ }^{81}$ Ibid., 24, 77-78.

${ }^{82}$ Robert F Sittig, "Campaign Reform: Interest Groups, Parties, and Candidates," Annals of the American Academy of Political Science 537 (January 1995): 93.

${ }^{83}$ Corrado, 27; FEC, Twenty Year Report, 12.

${ }^{84}$ Placing incumbents' voting records in these guides would probably be prohibitively expensive, but incumbent accountability reports would be a beneficial complement to voters' guides. Although some newspapers list local lawmakers' votes and some interest groups develop voting indexes, perhaps local League of Women Voters chapters or other non-profit organizations, freed of the financial burden of debates, could concentrate efforts on incumbent accountability reports.

${ }^{85}$ Morin, C1.

${ }^{86}$ Dan Drew and David Weaver, "Voter Learning in the 1988 Presidential Election: Did the Debates and the Media Matter?", Joumalism Quarterly 68, no 1/2 (spring/summer 1991): 37.

${ }^{87}$ Marion Just, Ann Crigler, and Lori Wallach, "Thirty Seconds or Thirty Minutes: What Viewers Learn from Spot Advertisements and Candidate Debates," Joumal of Communication 40, no 3 (summer 1990): 131.

${ }^{88}$ State of Oregon, Secretary of State, Voter's Pamphlet, State of Oregon Primary Election, May 17, 1994, 1994.

${ }^{89}$ Debbie Hembree, Oregon Secretary of State's Office, telephone interview by author, 15 November 1995.

${ }^{90} \mathrm{FEC}, 1994$ Congressional Fundraising, 1.

${ }^{91}$ Dan Balz and John F Harris, "Negativism Abounds on Primary Eve," The Washington Post, 20 February 1996, A1. 


\section{Bibliography}

Alexander, Herbert E, and Monica Bauer. Financing the 1988 Election. Boulder, Colo.: Westview Press, 1991.

Babcock, Charles R. "Money, the Senate and Running for Election." The Washington Post. 7 March 1994.

—. "Parties Raised Nearly $\$ 60$ Million in 'Soft' 1995

Donations." The Washington Post. 11 March 1996.

Balz, Dan, and John F. Harris. "Negativism Abounds on Primaty Eve," The Wasbington Post. 20 February 1996.

Balz, Dan, and Thomas B. Edsall. "Rivals Take Aim in Carolina Debate." The Wasbington Post. 1 March 1996.

Bauer, Robert F., and Doris M. Kafka. United States Federal Election Law. Dobbs Ferry, N.Y.: Oceana Publications, 1984.

Broder, David S. "Competitive Politics Costs." The Washington Post. 23 June 1993.

—. "Gingrich's Heresy." The Wasbington Post. 14 November 1995.

-. "A Senate of Millionaires." The Washington Post. 17 January 1996.

Buckley v. Valeo. 424 U.S. 1 (1976).

Common Cause. Editorial Memorandum: Congress Achieves Major Breaktbrough on Campaign Finance Reform; Bipartisan Legislation Sets Stage for Reform Action. Washington, D.C.: Common Cause, September 1995.

Corrado, Anthony. Paying for Presidents: Public Financing in National Elections. New York: The Twentieth Century Fund Press, 1993.

Drew, Dan, and David Weaver. "Voter Learning in the 1988 Presidential Election: Did the Debates and the Media Matter?" Joumalism Quarterly 68, no. 1/2 (spring/summer 1991): 27-37.

Dyckman, Martin. "A Test of Money's Grip." St. Petersburg (Fla.) Times. 1 February 1996.

Eagleton Institute of Politics, telephone survey of likely voters in New Jersey. New Brunswick, N.J. 25 October 1992. Polling the Nations CD-ROM.

Edmonds, Thomas N. "Campaign Finance Reform: Let the People Do the Talking," The Washington Post. 26 February 1994.

Federal Election Commission. 1994 Congressional Fundraising Climbs to New High. Washington, D.C., 28 April 1995.

-. Campaign Guide for Congressional Candidates and Committees. Washington, D.C., December 1995.

- Federal Election Campaign Laus. Washington, D.C., June 1994.

-. Twenty Year Report. Washington, D.C., April 1995.

Fiore, Faye. "Feinstein Critics Assail Election Reform Stance." The Los Angeles Times. 17 September 1995.
Hembree, Debbie. Telephone interview by author, 15 November 1995.

Hill, Steven. "For Campaign Finance Laws That Work, Look Abroad." Cbristian Science Monitor. 28 February 1995, 19.

Institute for Social Research, University of North Carolina, national telephone survey. Chapel Hill, N.C. 17 November 1994. Polling the Nations CD-ROM.

Just, Marion, Ann Crigler, and Lori Wallach. "Thirty Seconds or Thirty Minutes: What Viewers Learn from Spot Advertisements and Candidate Debates." Journal of Communication 40, no. 3 (summer 1990): 120-33.

Jones, Ruth S. "Contributing as Participation." In Money, Elections, and Democracy: Reforming Congressional Campaign Finance, edited by Margaret Latus Nugent and John R. Johannes, 27-45. Boulder; Colo.: Westview Press, 1990.

Kuntz, Phil. "The Money Chase: A Day in Washington Is Just Another Day to Raise More Dollars." The Wall Street Joumal. 23 October 1995.

Kurtz, Howard. "Slash Attacks Remain A Big Hit in Televised Advertising," The Washington Post. 26 September 1994.

Lewis, Charles. "Money: No Minor Matter in Politics." The Washington Post. 12 February 1996.

Lind, Michael. "Me and Mrs. Smith." The New Republic, 5 February 1996, 16-18.

Magleby, David B., and Candice J. Nelson. The Money Chase: Congressional Campatgn Finance Reform. Washington, D.C.: The Brookings Institution, 1990.

McBride, Ann. "Don't Give Up on Washington." Social Policy 26, no. 1 (fall 1995): 15-16.

Morin, Richard. "You Think the Congress is Out of Touch? Look in the Mirror, Voters, the Trouble Starts with You." The Washington Post. 16 October 1994.

Morris, Dwight, and Murielle E. Gamache, Gold-Plated Politics; The 1992 Congressional Races. Washington, D.C.: Congressional Quarterly, 1994.

Mulford, Ross Clayton. "Laws Must Be Nonpartisan Not Bipartisan." Social Policy 26, no. 1 (fall 1995): 12-13.

Nelson, Candice J. "Loose Cannons." In Money, Elections, and Democracy: Reforming Congressional Campaign Finance, edited by Margaret Latus Nugent and John R. Johannes, 4768. Boulder, Colo.: Westview Press, 1990.

The New York Times. national telephone survey. New York, N.Y, 23 October 1992. Polling the Nations CD-ROM.

Nugent, Margaret Latus, and John R. Johannes, "Inttoduction; What Is at Stake?" In Money, Elections, and Democracy: Reforming Congressional Campaign Finance, edited by Margaret Latus Nugent and John R. Johannes, 1-16. Boulder, Colo.: Westview Press, 1990.

Office of Representative Linda Sinith. The Bipartisan Clean 
Congress Act of 1995, H.R. 2566, Short Summary.

Washington, D.C., January 1996.

- Section-by-Section Summary of H.R. 2566, The Bipartisan Clean Congress Act of 1995. Washington, D.C., January 1996.

-. Sponsors of H.R. 2566. Washington, D.C., January 1996.

Office of Senator John McCain. Overview of McCain/Feingold/Thompson Campaign Finance Reform Bill. Washington, D.C., January 1996.

Sabato, Larry J. PAC Power: Inside the World of Political Action Committees. New York: W.W. Norton \& Company, 1984.

Schram, Martin. "Shakedown." Motber Jones, September 1994, 28-31.

Sinclair, Jon R. "Reforming Television's Role in American Political Campaigns: Rationale for the Elimination of Paid Political Advertisements." Communications and the Law 17, no. 1 (March 1995): 65-97.

Sittig, Robert F. "Campaign Reform: Interest Groups, Parties, and Candidates." Annals of the American Academy of Political Science 537 (January 1995): 93.

Smith, Bradley, "Campaign Finance-Deformed." The Wall Street Joumal. 6 October 1995.
State of Oregon, Secretary of State. Voter's Pampblet, State of Oregon Primary Election, May 17, 1994, 1994.

Stern, Philip M. The Best Congress Money Can Buy. New York City: Pantheon Books, 1988.

Teixeira, Ruy A. The Disappearing American Voter: Washington, D.C.: The Brookings Institution, 1992.

Times-Mirror for the People \& the Press. national telephone survey, Washington, D.C. July 8, 1992. Polling the Nations CD-ROM.

U.S. Constitution, art, 1, sec, 2-3.

Weir, Ellen. "Building Pressure for Campaign Finance Reform." The National Voter; March/April 1996, 2.

Yankelovich Partners, Inc. national telephone survey. Washington, D.C. 22 October 1990. Polling the Nations CD-ROM.

Zhao, Xinsht, and Steven H. Chaffee, "Campaign Advertisements Versus Television News as Sources of Political Issue Information." Public Opinion Quarterly 59, no. 1 (spring 1995), 41-65.

Zoroya, Gregg. "Suburban Candidates Find Some Broadcast TV Stations Don't Want Their Business." The Wasbington Post. 11 September 1994. 